\title{
16
}

\section{Reassembling informal gold-mining for development and sustainability? Opportunities and limits to formalisation in India, Indonesia and Laos}

\author{
Keith Barney
}

In the past two decades, research activity and policy development have intensified on the issue of formalising artisanal and small-scale mining (ASM), or informal mining. Numerous experts and influential institutions, including the World Bank, now view formalisation and legal registration as primary policy responses to the socio-economic, environmental and human health-related challenges posed by illegal or informal mining (see, for instance, Siegel and Veiga 2009; Maconachie and Hilson 2011; World Bank 2013). A number of African countries have made substantial progress towards the formalisation of artisanal and smallscale gold-mining (ASGM) through establishing legal rights for miners, with Ghana implementing initial provisions as early as 1989 (Maconachie and Hilson 2011). In the Asia-Pacific, Mongolia has arguably emerged at the forefront of formalisation through the provision of small-scale and community mining licences (Purevjav 2011); indeed, the Mongolian Government now views ASGM as important for maintaining national economic stability in the country's post-commodity boom era (Financial Times 2014). Bougainville Island passed its notable Mining Act 2015, 
which contains legal provisions for small-scale mining that would involve local authorities in regulating this activity (O'Faircheallaigh et al. 2016). There has been more partial policy support for community mining licences and permits in countries including the Philippines (Verbrugge 2014a), Indonesia (Spiegel 2012) and Cambodia (Cuddy and Seangly 2015; Spiegel 2016). Yet, overall across the Global South, progress with connecting the insights of applied research and advocacy into national policy frameworks and moving formalisation to the forefront of mineral governance agendas has been uneven and halting at best (Hilson and Gatsinzi 2014). In some country contexts, such as Zimbabwe, established policies supporting ASGM have been subject to rollback and renewed political contestation (Spiegel 2009). Many other mineral-rich countries, such as India and Lao PDR, remain ambivalent towards formalisation as a route for addressing the social and environmental externalities and promoting rural economic livelihoods (Moretti and Garrett, this volume).

This chapter draws upon empirical fieldwork conducted in three locations in India, Indonesia and Lao PDR between 2013 and 2016, as part of a multicountry research project aimed at understanding the role of new technologies in informal mining, and the relationships between ASGM, farmers and agrarian transitions in Asia. I examine key variations in ASGM practices and governance contexts as a basis for better understanding the potential role of legal formalisation. The cases illustrate how there is no singular ASM gold economy and, thus, there are distinctive potentials and challenges for formalisation initiatives across different country contexts and regions. To better understand this complexity, I locate the historically mediated process whereby different, grounded socio-natural ASGM 'assemblages' (as involving combinations of gold-bearing tracts; mining-agrarian populations, technologies and practices; market arrangements; civil society groups and transnational actors; and state institutional governance relations) become organised and relationally territorialised in particular places (see Collier and Ong 2005; Li 2007; Ouma et al. 2013; Vandergeest et al. 2015). Such assemblages of informal mining, the regimes of extraction and the distributions of surplus and rents, take form through multi-scaled state-society relations, and are mediated through diverging agrarian transitions and distinct historical trajectories of resource governance (Peluso 2016).

The complexity and diversity of informal arrangements in the three mining sites contribute to the primary arguments put forth in this chapter. First, I argue that formalisation interventions would necessarily need to be 
conceived in relation to the scale and organisation of the informal mining assemblage in question-from the micro-artisanal end to the mediumscale mechanised end of the spectrum. Second, technical templates for formalising informal mining, as a way of engaging with the sector's social and environmental challenges, are unlikely to gain traction. ASGM initiatives could instead seek to connect with civil society and be responsive to local collective actions, thereby developing informed, grounded understandings of local livelihood contexts in ongoing mining-agrarian transformations, and of the political and class-based struggles occurring in ASGM communities. Third, in medium-scale ASGM contexts, there can be significant trade-offs between ecosystems and agrarian sustainability and local health concerns on the one hand, and income generation from ASGM operations on the other. Regularisation and formalisation initiatives in Asia would face difficult choices between these priorities; such shades of grey could heighten political risks to external intervention. Such environmental politics are also reflected within local communities themselves, in terms of their debates and contestations on the appropriate pace, scale and location of informal mining.

The cases themselves also present novel insights into the political and governance arrangements for informal mining in each country context. In Jharkhand state in India, I argue that formalisation as basic regularisation would represent a necessary first step for supporting miners' livelihoods, lifting the burden of restrictive state control and promoting the basic right of the poor to access and extract minerals. In practice, the political ecology of informal mining in Jharkhand is framed through distinctive federal, state and local-adivas $i^{1}$ resource politics and contested social struggles (Shah 2013). In Central Kalimantan, Indonesia, there is potential to progress with ongoing state formalisation reforms, in a context where mechanised 'medium-scale' gold dredging, on both land and rivers, can represent a profitable rural enterprise. Here, as well, the burden of petty exploitation visited by local police upon the poorest and most marginal miners relegates some ASGM activity to the suppressed 'illegal' sphere, with pernicious results for the poor (see also Spiegel 2012). In Central Kalimantan, formalisation reforms require careful consideration, as the more capitalised end of the informal mining sector involves a distinctive

1 An umbrella term used to denote a heterogeneous group of tribes and indigenous group of people in India. 
extractive assemblage, operating in connection with local authorities, which can be associated with clearly negative impacts on common pool resources, particularly for fisheries and aquatic habitats.

In Lao PDR, the last decade of neoliberal-inspired mining reforms has focused policy formulation on the large-scale corporate mining sector, neglecting the long tradition of local people's mining (cf. Maconachie and Hilson 2011). Agrarian displacement due to state-backed, large-scale land acquisitions for resource development has been identified as an important 'push' factor for local farmers to seek cash income though involvement in informal gold-mining (Insouvanh 2015). Despite a centrally issued moratorium on new mining concessions, in Lao's southern Xekong Province, fieldwork documented medium-scale dredging and sluicing by cross-border Vietnamese (and Lao) 'backhoe' miners on former streamside rice paddy fields. Here, as well, a more mechanised, medium-scale range of informal mining and its transnational connections present governance challenges with few easy solutions.

This chapter thus develops a critical interpretation of the formalisation literature as related to ASGM, and outlines the significant heterogeneity of informal mining practices and governance arrangements across field sites in India, Indonesia and Laos. The study concludes with reflections on the potential pathways and limits to formalisation beyond a technical policy 'fix'. It explores how applied participatory research programs might seek to more rigorously understand ASGM assemblages and to identify practical policy options that are responsive to collective actions and social mobilisations, involving both informal gold miners as well as broader agrarian communities.

\section{Conditions of informality in artisanal and small-scale gold-mining}

The terminology and concept of 'informal mining' is useful for moving beyond state-centric discourses of illegitimacy and illegality, and for recognising the sector's crucial role in numerous Global South rural development contexts. This chapter does not approach formalisation through a step-wise template, or an easily replicable 'formalisation fix' (Dwyer 2015; Spiegel 2016). Instead, we can understand ASGM in relation to multi-scaled mineral regulatory regimes, contested political 
ecologies and situated mining practices and territorialisation, all of which are enmeshed in contexts of ongoing struggles for livelihood, rights and recognition in agrarian-mining communities (Tschakert 2009a, 2009b, 2016; Singo and Levin 2016). Following Lahiri-Dutt (2004), I view ASGM not as an anachronistic, preindustrial activity, nor as primarily a subsector of modern corporate mining. I also avoid locating ASGM primarily through the lens of state corruption and uncontrolled extraction, or as necessarily tied to negative social outcomes-for example, in discourses of informal mining as 'fast money' just as quickly spent by miners on alcohol, drugs, gambling and prostitution. While there can be exploitative social relations in ASGM, such peasant mining can also be understood as part of a vibrant, vast, historically significant 'informal economy' operating largely outside of modern private and public institutions. In Hart's (n.d.) interpretation, the informal sector is that segment of the economy that is 'irregular, unpredictable, unstable, even invisible'. As Hilson $(2013,2014)$ notes, it is also important to understand how the informal mining economy can be actively reproduced by state and donor policies, and to understand the environmental challenges posed by ASGM, not as a technical environmental management issue, but rather as a 'development problem with an environmental dimension'. This move places miners and local mining-dependent communities, their political and economic concerns and their livelihood struggles as the starting points for analysis.

\section{Critical research on ASGM and informality}

The work of Hernando De Soto (2000) serves as the starting point for research on ASM formalisation. De Soto's framework lends support to a 'legal system that transforms assets into capital' (Hall 2004: 402), and builds upon notions of the (potential) entrepreneurialism of the poor. Siegel and Veiga (2009) situate their analysis of informal mining within this frame, in which the creation of formal, legal property rights is conceived as a key (albeit not exclusive) basis for effective poverty reduction and improved regulation. Formalisation is viewed as a process with three basic elements: a right to land title, a right to minerals and a right to mine. A series of supporting reforms would accompany this, including legalised trading rights; the clarification of overlapping or muddled legal frameworks; and the streamlining of bureaucratic obstacles that can limit smallholder formalisation in practice. Siegel and Veiga (2009) also note that formalisation is at times avoided by informal miners, 
as it can create new bureaucratic costs and overheads, and limit flexibility in accessing new mining sites. Along these lines, Barreto (2011) advocates for establishing clear legal, spatial planning and zoning frameworks for ASM, followed by targeted policy packages for legalised miners, including support for technological upgradation, new techniques and mining methods, improved labour and environmental management standards, advice for business development and access to formal credit.

Tempering the neoliberal-inflected views of De Soto, Buxton (2013: 6) points to a paradox of informality, in that it can 'both increase resilience by providing an economic livelihood activity and increase vulnerability as it removes the protections and opportunities provided by the government'. Buxton outlines informality, livelihood vulnerability and marginalisation as three core and recursive social processes characteristic of ASM. Recognising the numerous barriers that serve to block effective reforms in informal mining, Buxton argues for new types of structured 'knowledge networks', as institutional vehicles for participatory research and engagement (see also Barreto 2011). Given the huge array of informal mining practices across different countries, formalisation could have intended or unintended exclusionary consequences—-for instance, through high licensing fees, and creating new hierarchies between legalised and capitalised small-scale operators and more actively criminalised miners. Thus, critical ASM observers caution that formalisation does not represent a singular solution to the negative manifestations of informal mining (see Langston et al. 2015). Formalisation programs could, however, tap local knowledge and invite the participation of miner organisations to build more pragmatic, responsive and effective regulatory frameworks (Barreto 2011; United Nations Environment Programme (UNEP) 2012).

Hilson (2013) and Hilson and Gatsinzi (2014) further emphasise that the informal ASM economy is not a phenomenon that is external to the power and territorial authority of the state. They identify how the conditions and incentives for informality are continually reproduced, not only due to bureaucratic complexity and high transaction costs of legal compliance, but other factors as well (De Soto 2000). Also at issue are inappropriate or poorly coordinated policy interventions into the informal sector, the favouring of corporate mining interests in policy frameworks and persistent state underinvestment in sustainable agrarian livelihoods. These authors reiterate that the informal sector is not necessarily founded in smallscale miners' intentional avoidance of taxes and government regulation, as indeed it is very often the selective and exploitative involvement of state 
actors, such as the police and military, that can reinforce the underground, patronage-based 'shadow state' (Reno 1999) character of the informal mining economy (Peluso 2018).

Of critical importance is how locally mined gold is transformed into a global commodity. Fold et al. (2014) elaborate on the complex geographical co-production of formal and informal gold value chains. A key implication of their analysis is that any formalisation program would need to be based upon a clear understanding of the socio-spatial organisation of both formal and informal gold value chains, examining how and where these merge into a single marketing chain, and tracing through how certain gold commodity markets can lock in exploitative labour arrangements and poor environmental practices. Along these lines, significant efforts have been made in recent years to connect legalised and fair trade artisanal gold production to buyers in the Global North. Here, Singo and Levin (2016) argue that a 'failure to formalise' stymies efforts to restructure how artisanal gold miners are connected with global gold markets:

If miners don't formalise, they can't professionalise. Without professionalisation, miners are not able to accommodate the due diligence requirements of 'responsible' buyers. This exacerbates buyer disengagement.

Such double (indeed triple) binds with producing and marketing 'sustainable' ASM gold are characteristic of the political economy of informal mining.

In his recent work, Boris Verbrugge has significantly extended our understanding of the political economy of informal mining through a sophisticated historical-geographical examination of the state and capital interests that support ASGM activity in the southern Philippines. Verbrugge (2014a, 2014b) argued that potential formalisation policies need to be more closely considered in relation to the internal and external power relations that structure overall labour-capital dynamics of ASM. He characterises complex governance regimes of ASGM in Mindanao as comprised of multi-tiered labour structures, linked in various permutations to the 'capital interests' of local state officials. In the Philippine uplands, such politically sanctioned informal mining can take on highly exploitative and hazardous forms, including forms of debt bondage. This is occurring in a context of elite consolidation and upland state formation, as well as a national policy shift away from large-scale mining (Verbrugge 2015a). 
For Verbrugge (2014a), tracing the connections between informal mining and elite interests in Mindanao requires detailed political economic analysis, based on a grounded understanding of the context of mineral governance, the politics of decentralisation and the dynamics of local politics in southern Philippines.

Verbrugge (2015b) also offers new insights into the political relations and forces of capital that structure emergent class hierarchies between a poverty-driven labour force and informal ASM entrepreneurs. Conceptually, this move focuses attention on 'the diverse origins and implications of informality in ASM ... the vested interests in the (partial) persistence of informality, in the form of a labour force that is bereft of formal legal recognition and vulnerable to exploitation' (ibid.: 1042). Verbrugge thus provides a detailed and grounded examination of power, marginality and labour exploitation in ASGM in the Philippines, examining the reproduction of domination through changing regimes of mining governance. In this way, Verbrugge and Besmanos (2016) draw attention not just to the rights of mineral resource tenure claimants, but also to the labour conditions of highly exploited workers.

While work from scholars such as Verbrugge identify the complex terrain of political-economic power relations in ASGM, critical observers such as Labonne (2014) voice a strong pessimism regarding the actual potential for formalisation and other pro-poor state policy interventions to introduce positive changes. In a blunt challenge, Labonne (ibid.: 123) argued that ASM formalisation is more likely to emerge from 'the success of governments in combating poverty in the non-mining rural communities'. While caution on the prospects for formalisation is surely warranted, agrarian studies scholars have also argued that contemporary agricultural labour markets are often insufficient for reducing rural poverty (Otsuka et al. 2010). In many contexts, poverty and underdevelopment, as well as new livelihood opportunities, are created through rural people's interactive engagement in both agrarian and mineral-based activities, and thus Labonne's analysis risks an undue compartmentalisation between these livelihood portfolios. Simply refocusing policy interventions upon improving agrarian livelihoods and facilitating urban-industrial transitions is unlikely to be an adequate response to the challenges of ASGM in many contexts. 
This review of the core and current debates on ASM and formalisation adds significant complexity to governance interventions founded upon either top-down regulatory enforcement or a neoliberal, market-friendly approach based upon the simple legalisation of property rights as a path to a more sustainable and beneficial form of rural people's mining. I next turn to briefly reviewing variations in ASGM practices and organisational forms as a basis for discussing the prospects and limits of formalisation in the three field cases.

\section{The diversity of ASGM assemblages and practices}

A wide heterogeneity of sites, actors, technologies and practices, institutional-capital arrangements and agrarian-environmental relations characterise informal and small-scale gold-mining. Veiga (n.d.) usefully distinguishes between three broad clusters that are often grouped together as ASGM: a) micro-scale, informal, artisanal; b) small-scale, illegal, semimechanised; and c) medium-scale, illegal, mechanised. On the microartisanal side, ASGM can involve relatively independent peasant miners working marginally productive alluvial gold tracts, experiencing high levels of vulnerability and holding subordinate livelihood positions within the local agrarian economy, but who also find support through non-market access to gold and other market or subsistence-based ecological resources. Towards the more medium-scale end of the spectrum, informal goldmining moves into more complex organisational and hierarchical labour arrangements, working deeper and more valuable alluvial, hard rock or riverine deposits with more significant levels of technology, investment and debt relations and operations linked to powerful business interests and political patrons (Verbrugge 2014a; Verbrugge and Besmanos 2016). This form of mining can even involve transnational capital connections. Across this range, informal gold-mining is also characterised by changing socio-technological practices, multi-scaled governance systems, varying degrees of miners' geographical and livelihood mobility and complex socio-environmental transformations (Verbrugge et al. 2015; Ferring et al. 2016).

This diversity of ASGM actors, practices, institutional arrangements and environmental outcomes has significant implications for program and policy development on formalisation. Indeed, Ferring et al. (2016) question the extent to which this diversity is actually reflected in current policy discourses on ASGM in Ghana, a key informal gold-producing 
country. ${ }^{2}$ Insufficient recognition of the heterogeneity of informal mining could limit the scope for formalisation initiatives to particularly favourable sites, rendering policy interventions ineffective on a broader scale. Even under optimal conditions, the formalisation of small- and medium-scale mining would often involve complex reallocations of resource access and property rights, as ASGM typically monopolises and even eliminates most future land uses (Putzel et al. 2014). There is also no guarantee of improved environmental performance through increased legal regulation (MacDonald et al. 2013).

Where does this understanding of the political economy of persistent informality, and of highly complex and diverse ASGM governance regimes and assemblages, broadly lead us in terms of policy approaches to formalisation? Most basically and directly, these factors would pose significant challenges to the effectiveness of expert-led, sectorconstrained, technical-based formalisation policy reforms. Insights can be drawn from Michael Dwyer's (2015) perspective on the formalisation of land tenure and ownership in Cambodia through donor-supported land titling programs as a 'formalisation fix'. Dwyer usefully highlights a need to extend beyond technical-driven policy interventions, and towards a grounding of formalisation policies within distinct, spatialised and place-based historical-geographical contexts and socio-political struggles (see also Bridge 2002; Peluso et al. 2012; Spiegel 2016). A close understanding of the local political ecologies and political economies of informal mining might better reveal the democratic possibilities, as well as some hard realities of formalisation as a legal policy approach.

I draw upon the above literature to examine local ASGM assemblages in three field sites: in India, Indonesia and Laos. I direct analysis into the realm of state-capital interests, and hierarchical labour regimes in ASGM that reproduce vulnerability and establish the conditions for perpetuated (Spiegel 2012) or persistent (Verbrugge 2015b) informality. I locate these variations in relation to the material and environmental realities of mining activity; to agrarian-ecological class relations (Akram-Lodhi et al. 2010); and to local socio-political struggles for rights to livelihood by both local miners and resource-dependent communities.

2 Drawing upon Mitchell (2002), Ferring et al. (2016: 3) identify a managerialist impulse in new donor and policy frameworks aimed at regulating and formalising small-scale mining, which can be based upon unwarranted simplifications: 'Actually existing complexity is discursively erased in policy and other official representations so that a particular type of expert and intervention can rule'. 


\section{Territorial assemblages of informal gold-mining}

\section{Artisanal-peasant gold-mining along the Subarnarekha River, Jharkhand state, eastern India}

Indigenous (adivasi) or tribal people have a long history of shallow alluvial gold panning and mining along the lower Subarnarekha River (the 'thread of gold') in India's eastern Jharkhand state. The local mining taking place in the Subarnarekha watershed is typically unregulated, irregular and based upon seasonally ephemeral gold resources. Lahiri-Dutt (2004) refers to such peasant mining as an 'elusive, unquantifiable and uncertain section of the mineral economy' (ibid.: 123), while the autonomous and informal structure of such activity renders it 'conceptually, methodologically and theoretically difficult to define in terms of its precise nature, size and significance' (ibid.: 126).

Deb et al. (2008: 195) identify the majority of miners and practices in these locations in India as informal or 'non-legal' (as opposed to illegal), as mining is carried out 'beyond the purview of the law'. Gold is classified as a 'major' mineral under India's Mines and Minerals Act 1957, and legally any gold-mining occurring more than 6 inches beneath the surface is prohibited. Thus, the federal Indian Government allocates gold-mining permits to large-scale miners only (Lahiri-Dutt 2004). In practice, as Deb et al. (2008: 207) observe, the '[l] ack of available official or unofficial data related to the practice of artisanal mining in India makes the whole issue very nebulous'. In Jharkhand, I suggest that any effort to support artisanal miners' livelihoods and to improve practices would face a number of challenges, in terms of the low intensity, spatially dispersed and relatively marginal economic value of the resources currently extracted, and the rather poor prospects for Indian state policy reform. Indeed, ASGM is the target for periodic crackdowns by the provincial and district constabulary, while the state promotes investments into larger-scale, capitalised gold-mining in the Subarnarekha watershed (Bose 2015). ${ }^{3}$

3 In Seraikela-Kharsawan district, Geological Survey of India has been drilling since May-June 2011, where there are potential reserves of gold (Bose 2015). 
Fieldwork in Jharkhand's Seraikela-Kharsawan District in February 2014 highlighted two miner communities. The first involved women microscale miners, working in small groups but panning on an individual basis or with children assisting. Village women were panning for alluvial gold in low-lying agricultural lands along the banks of the Chandil Reservoir, using basic hoes and wooden pans (donga), scraping the soil surface and panning for minute particles of gold. The local historical context is important to their livelihood situation. The Chandil Reservoir was created in 1983 through the World Bank-funded Subarnarekha Multipurpose Project (SMP), involving a series of barrages and canals targeting electricity generation and irrigation. The major Chandil and Icha dam components of the SMP involved the flooding of some 30,000 hectares of local farms and forest lands; the under-compensated displacement and resulting impoverishment of approximately 68,000 adivasi people in 160 villages (with 38 settlement sites submerged); and the imprisonment and violent deaths of a number of protestors and community leaders by local security forces in the late 1970s and early 1980s (Probe Alert 1991). Notably, the Chandil Dam, as well as other reservoir projects, also submerged productive sites of traditional gold extraction by local adivasi communities (Lahiri-Dutt 2004; Bose 2015). During our fieldwork, we also encountered evidence of colonial-era gold-mining infrastructure (old elevated roadways, stone-reinforced tunnels) that testifies to this history of mineral extraction in the area.

While ethnic Santhal ${ }^{4}$ men plough agricultural fields or undertake evening-time reservoir fishing, women pan for gold along the water's edge, or travel upstream to pan at the Subarnarekha's confluence. Artisanal gold-mining is an important means of supplementing agricultural, wage labour and subsistence livelihoods. The ecological impacts from their activities would be negligible, as they do not use mechanised digging equipment or sluice boxes, or mercury for gold amalgamation. Their low capital-intensive gold-extraction activities are not a matter of concern to local officials, which is likely why such adivasi women are able to continue to access and exploit this local resource.

One elderly female village informant pithily identified a number of intersecting livelihood issues:

4 One of the largest adivasi groups in India, with an estimated population of some 2.4 million in Jharkhand state. 
In one week I can get one lakh rupees, or nothing. ${ }^{5}$ Our old farming land is now the home for fish ... [But] we don't get a fair price [from the gold traders], and it's not enough to keep our stomachs filled. (Interview, 3 February 2014)

For these women, the painstaking work of daily panning for gold represents an important contribution to household livelihoods, following their historical displacement due to a major infrastructure project. This relationship between population displacement due to large-scale projects and subsequent 'informal' access to remaining niche common property resources has been a recurrent theme in the literature on developmentinduced displacement (see, for instance, Kibreab 2000). In Jharkhand, women's engagement with micro-artisanal mining is moreover based upon an explicitly gendered access to localised gold resources, which is at a small enough scale not to concern local officials, who can act to block miners' access to waterways for mining in other nearby locations (Bose 2015).

Another group of gold miners we interviewed, who were also displaced from the original SMP, involved a community of approximately 50 male miners. The men were working in two groups, digging pits of up to $4 \mathrm{~m}$ deep along the dry season bed of the Subarnarekha River, about $8 \mathrm{~km}$ downstream of the main barrage, and some $15 \mathrm{~km}$ upstream from Jamshedpur city. As the agricultural season ends, local ethnic Mundari (adivasi) men bicycle daily from villages up to $20 \mathrm{~km}$ away to undertake gold extraction as an alternative to wage labour in nearby brick kilns, or cutting sawn wood for sale from local forests. This form of mining involves more specialisation in labour activities and the use of diesel hydraulic pumps to increase extractive capacity. ${ }^{6}$ During our visit, two different work teams were subdivided into task groups, removing rocks and boulders, scooping water and carrying sand from the streambed for panning. Gold is sold to a single trader at the local Chandil market, at a reported price of INR2,300 (US\$37) per gram (representing a 22 per cent discount on the India spot price for gold on that day). ${ }^{7}$ Miners reported that daily profits were shared equally amongst work team members. At an upper estimate of group production of approximately 8 grams of gold per

5 INR 10,000 , or approximately US $\$ 150$. The reported value may have been more of a rhetorical flourish. Tarun Bose (2015: 10) reports that women from nearby Moisara village could earn INR300400 (US\$4.80-6.40) per week on average from a similar style of gold-mining.

6 Purchase price of diesel pumps at INR15,000/US\$242 per pump; averaging 20 litres of fuel per day, costing INR1,000, or US\$16.

7 To compare, India gold spot price on 4 February 2014 was INR2,969/gram: www.goldpriceindia. com/gold-price-february-2014.php. 
day, the gross yield of a work team of 25 members might represent some INR18,400 (US\$294). Subtracting daily fuel costs of US\$16 provides net revenues of US $\$ 278$, or US $\$ 11$ per worker, if shared completely evenly (purchase and maintenance cost of pumps, compensation for the owner of the machinery or investor, and any other fees also need to be subtracted). In interviews, individual wages were also reported to lie between INR50 and 250 per day (US\$0.80-4.00), so their average daily income is perhaps within these lower and upper bounds, depending on the organisational structure of the work teams and rates of gold recovery from the riverbed. ${ }^{8}$ Local miners indicated that if they were discovered finding larger gold pieces, or if they ventured further into higher horsepower pumping machinery, it would attract the attention of local officials (field interviews, 4 February 2015). While their mining activities are quite visible, these miners generally aim to operate outside of the focus of attention of local officials as much as possible.

The broader issue in these adivasi lands in Jharkhand, identified by researchers such as Alpa Shah (2013), is that of a stalled agrarian transition. Historic Jharkhand witnessed neither an agricultural consolidation by a landlord class, nor a capitalist transition to commercial agrarian commodity production. To be sure, in Jharkhand, forests have been logged and liquidated, major mineral resources are controlled by private or state-owned corporations, including Coal India, and large-scale state development projects, such as the SMP, have produced significant enclosures and dispossessions. Yet, Shah (2013) argues that the majority of the region's rural population has been situated outside of the primary circuits of capital, assembling a multifocal livelihood through lowproductivity family-based agriculture, and non-market based access to increasingly marginal natural resources, including gold and forest products. In response to this rural crisis, there is widespread engagement in regional labour migration under highly precarious circumstances, while demographic pressures contribute to increasing levels of rural landlessness and pauperisation (ibid.). An ongoing Maoist insurgency in Jharkhand (including various splinter groups in competition with each other) leverages upon conditions of poverty and rural discontent, which in turn can invite heavy state and police pressure, including on peasant gold extraction activities that extend beyond an acceptable scale.

8 There can be constraints with securing accurate information on daily income from ASGM, as miners have a broad interest in not drawing attention to their activities. 
While clearly important for the communities involved, the small and micro-scale subsistence-supporting nature of peasant gold extraction activity, an ongoing political situation involving disaffected Maoists, and the relative degrees of suppression of gold-mining by local state actors, would make this a challenging arena for policy intervention. Deb et al. (2008: 200) advocate for local governments (Panchayats) to play a supporting role in artisanal mining under their jurisdiction, and propose a review of state regulatory frameworks to remove ambiguity around the legality of ASGM sites. ${ }^{9}$ Here, promoting a basic right of the poor to mine (rights over land, rights to trade and rights to basic working conditions) could potentially assist local gold artisanal panners and miners to secure a foothold in the formal economy, and possibly alleviate some of local conditions of extreme poverty. This would entail a reorientation of an often coercive relationship between local state actors and the rural poor, and would require support for the miners to advocate on their own behalf through collective organisations. However, in Jharkhand at least, there is little indication that state authorities are contemplating such reforms.

\section{Medium-scale informal gold-mining in Central Kalimantan, Indonesia}

Central Kalimantan has been represented in some of the largest and most contentious ASGM mining booms in the post-New Order period in Indonesia. Spiegel (2012) and Agrawal (2007) have examined a high-profile 'gold-rush' site at Galangan in Katingan District, Central Kalimantan, in detail. This heavily degraded area of about $50 \mathrm{~km}^{2}$ once attracted up to 10,000 miners, using pumps and dredges to work through the mineralised rainforest soils. Miners were drawn from local Dayak communities, from elsewhere in Kalimantan, as well as from Java and Madura. Spiegel (2012: 201) discussed the highly volatile and, at times, violent Galangan-Hampalit gold-rush site in relation to the ambiguous outcomes of administrative decentralisation, the diversity of participants in ASM mining, as well as the 'political and economic interests in perpetuating informality’. International Crisis Group (ICG 2001) also documents Galangan-Hampalit as a particularly contested site of struggles over natural resources. Indeed, a violent encounter between

9 Similar principles of involving local communities in ASM governance have been applied in the Bougainville Mining Act 2015 (see O'Faircheallaigh et al. 2016). I thank Matthew Allen for pointing me towards this. 
Dayak and Madurese miners provided the ignition trigger for the 2001 outbreak of ethnic violence between these two communities in Central Kalimantan.

In the forests and rivers of Katingan Regency and Gunung Mas (gold mountain) district, new 'rush' sites can still attract thousands of miners. Typical in-land mining methods involve the use of dredging pumps, sluice boxes and carpets, with a recovery rate for particles of gold reported as approximately 30 per cent. In a site visited in Gunung Mas, dredging pumps can work through $5-10 \mathrm{~m}^{3}$ of soil per day, eventually yielding approximately 5-10 grams of gold per day per team of four to seven miners, providing a gross revenue of some US\$153-307 per day. Some miners, working on an individual basis (using smaller but less costly pumps that use less fuel), might mine and sell their 'pay dirt' to other processors for onward gold recovery. Miners indicate that a primary calculus governing their activities is the ratio between diesel consumption and grams of gold yielded. Baseline labour costs are discounted, and the eventual net earnings of workers depend upon the value of gold their unit can extract from the rainforest soils or river bottoms.

Major rivers in Central Kalimantan, such as the Kahayan and the Katingan, and associated freshwater ponds that represent their former courses, have also been mined through floating dredging platforms, resulting in significant aquatic ecosystem impacts (see United Nations Institute for Training and Research (UNITAR) 2016). Despite its widely acknowledged environmental impacts, ASM is now a primary incomeearning activity in many communities along the major river systems of Central Kalimantan. Gold-mining is considered as more attractive than working in oil palm concessions (which pays as low as IDR30,000 per day for an entry-level worker, or US\$2.50), harvesting rattan, cultivating bananas or tapping rubber. Indeed, sharp declines in rubber and rattan prices in the past years have ushered more rural people into mining (fieldwork interviews, November 2014 and September 2016).

During a visit to the Galangan-Hampalit 'moonscape' (Spiegel 2012: 194) in November 2014, we encountered approximately half a dozen hardscrabble miners—ethnic Dayak, Javanese and Banjarese-working through the tailings long after the end of the main gold rush, in a bleak and heavily degraded landscape. For one miner, working autonomously without the protection of a 'boss', payments of up to IDR100,000 per month were still required to the local police. The man used an 'Alcon' 
brand of diesel pump, using 5 litres of fuel per day, and sold $30 \mathrm{~kg}$ of pay dirt to a local processor. A nearby Banjarese couple living in a rudimentary shack was in an even more precarious situation, estranged from their children due to their poverty, moving itinerantly around the Hampalit landscape in an attempt to avoid payments to the police. For these most marginal of miners, working the tailings from a previous gold rush offers a residual livelihood foothold. Lifting the burden of petty extortion by police forces (see also Spiegel 2012: 195) would seem to offer a first step for some improvement to these miners' desperate predicament.

More capitalised informal mining operations using pump and sluice box systems (for in-land mining), which can be placed upon mobile dredging platforms (for riverine mining), are the primary modes of informal goldmining present in these districts. Some district miner groups have gained livelihood security from formalisation systems through the combination of Wilayah Pertambangan Rakyat (WPR, Community Mining Areas) and the Izin Usaha Pertambangan Rakyat (IPR, Community Mining Licences). Formalised miners also require an environmental permit from the provincial and district environmental agency (Badan Lingkungan Hidup) in the form of an environmental impact assessment document, as well as environmental management and monitoring plans. However, our local informants indicated that formalised community mining licence arrangements required significant paperwork, ${ }^{10}$ while local authorities applied extremely high surcharges for the permits. Limited to 25 hectares, community mining licensing also limit mobility and flexibility in developing new mine sites, and thus would seem more readily suitable to fixed hard-rock deposits, rather than for more mobile and ephemeral alluvial gold-mining. For these reasons, the vast majority of alluvial mining groups in Central Kalimantan have avoided formalisation; indeed, some miners interviewed in September 2016 had never heard of the possibility of a formal licence.

In this legal grey zone, mining 'bosses' facilitate protection from police harassment for unit owners and their workers, as well as provide equipment, financing, (illegal) access to state-subsidised diesel fuel ('solar' in Bahasa) and gold-trading services in exchange for a share of unit profits. Local police also benefit from ASGM through controlling access to 'solar'. ${ }^{11}$ State-subsidised diesel (retailed at a discount of IDR5,050 per

10 See also Harvard Kennedy School (2011: 93) on the 'high cost of formality' in Indonesia.

11 'Solar' is the Bahasa Indonesian term for 'diesel'. 
litre, or US\$0.39) should be utilised only for personal and not business use. District police oversee quite a public and visible system whereby, in exchange for a fee, drivers of modified vehicles with expanded fuel tanks load up on 'solar' from petrol stations for onward delivery to gold miners or oil palm plantations, where it can be sold for IDR15,000-20,000 per litre (US\$1.15-1.54), depending upon the distance.

In Gunung Mas district, in association with a Dayak small-scale mining association (ASPERA-KT), we visited informal in-land mining sites occurring on individually titled, but formerly customary adat, forest land. The unit operations were run by small groups of local ethnic Dayak men, involving up to 7-15 workers per large dredging unit, with reported yields as high as 100 grams of gold per 200-litre drum of diesel fuel, which lasts for five days of dredging. ${ }^{12}$ From this gross yield, 50 per cent would be awarded to the land and unit owner-in this case, who held a land title issued by the National Land Agency, under the Ministry of Agrarian and Spatial Planning.

There is a recurring rhetoric that informal miners are engaged in drugs, and that their 'hedonic culture' contributes to a range of other social ills (interviews, Palankaraya, September 2016). However, local discussions in Central Kalimantan with both Dayak and migrant miners identified the use of mining income to pay for daily living costs, purchasing land or a vehicle, building a family house and forming a household, or for their children's schooling. Some miners did report that drugs could be used in order to maintain their energy during times when rich gold strikes were identified, and work continued through the night. A number of parents of young miners also indicated that drugs were an issue in ASGM (interviews, Katingan district, September 2016). However, it is not clear that gold miners are making a highly disproportionate contribution to the province-wide social ills of drugs, alcohol, gambling and prostitution.

12 On 27 November 2014, the reported Palankaraya gold shop purchase price was reported at IDR480,000 (US\$39.41) per gram, a 6.2 per cent discount on the international spot price for that day. Using 200 litres of diesel (worth perhaps US\$197), and with 50 per cent of revenues allocated to the investor/landowner, a unit team of 7-15 workers might then generate US\$125-267 per worker for a five-day 100 gram (3.5 ounce) yield of gold. This might then represent US\$25-53 per worker per day. Food costs need to be deducted; also, for the investor, capital depreciation for diesel pumps (US\$200/pump), sluices (US\$175 in materials) and carpets (US\$26/ $\mathrm{m}^{2}$ ). Note that this rate of return would represent a better-case scenario. Other interviews indicated estimates of worker's pay at US\$11-19 per day. All these calculations depend on the site, yield and recovery of the deposit, which are highly variable. Of course, some days can yield no gold at all for the miners. 
What is apparent, as others have noted, is that 'informal' mining in Indonesia is internally variegated, characterised by unequal power relations, connected to particular state institutions and actors, and operating through various relationships with formal state agencies (Peluso 2016, 2018). There is a notable comradely ethic amongst workers, and after the share held by the unit owner and landowner, the revenues from gold extraction are shared equally amongst a unit team. In Central Kalimantan, despite periodic provincial crackdowns and 'patrols' (see, for instance, Lingga 2016), it is possible to discuss the formalisation of local mining with local political figures, signalling a relatively more open and permissive political environment for local ASGM activity, as compared to Jharkhand or Laos.

The strongly ecological character of the mining-agrarian transition (Akram-Lodhi and Kay 2010) in Central Kalimantan is also apparent. In Murung Raya and Katingan regencies, the logging boom is long past, oil palm has not delivered benefits for wage labourers, while larger coal-mining companies have often brought conflicts over land. With draining of peat lands and the associated catastrophic El Nino dry season fires (McCarthy 2013), local observers point to a downward spiral of accelerating resource degradation and livelihood vulnerability. In turn, classic dilemmas have emerged between ASGM and common pool resources, especially involving waterways and fisheries. Informal mining does come at a heavy cost: land is permanently removed from productive use, fishing is no longer possible in many heavily degraded waterways and ponds due to dredging, and mercury contamination is very likely widespread, although the extent of contamination of environments and aquatic food chains is poorly documented (Agrawal 2007). Many villagers in fact voice opposition to gold-mining activities in their lands and river systems, even as mining activities are represented in most rural households along the provinces' major gold-bearing waterways, such as the Katingan River (fieldwork interviews, September 2016).

While many villagers have taken part in the successive Central Kalimantan resource booms, the majority of profits from large-scale resource development have been transferred out of the province. The transition has been too rapid and transformative for local communities to successfully engage with and adapt to the changes. Some community leaders seek a revitalised Dayak customary tradition that could be welded to modern economic and technological transformation, including local involvement in formalised and regulated gold extraction (fieldnotes, 
26 November 2014). Yet, the challenges of relying upon a positional indigenous Dayak identity and cultural traditions as a bulwark against unsustainable extraction are also evident (cf. Li 2000), with the widespread involvement and varied motivations and practices of miners; at times significant internal tensions within communities over regulating mining; accelerating mining-linked ecosystem degradation; and the significant numbers of migrants drawn from elsewhere in Indonesia into Central Kalimantan's new gold-mining rushes. Recently, the provincial government has promised 1,500 community mining licences as a step towards greater formalisation. However, the current permitting process for community mining areas and licences in Central Kalimantan is complex, costly and poorly organised, the procedures are not adhered to and formal permits are only used by a few dozen miners as a means of providing partial protection from police patrols (non-government organisation interviews in Palankaraya, 4-5 September 2016).

\section{Artisanal and transnational-mechanised informal mining in southern Lao PDR}

In the previous decade there was significant interest in research on ASGM in Lao PDR, and a series of publications were published on informal mining through the United Nations-backed Global Mercury Project (Boungnaphalom 2003). The last 15 years of World Bank-influenced minerals and mining policy reforms in Laos have facilitated the entrance of large-scale mining capital into the country (Hatcher 2015). Two national flagship gold and copper ventures at Xepon and Phu Bia were initially led by Australian mining companies (Oz Minerals and PanAust), but have since been purchased by Chinese firms (China MinMetals Group and Guangdong Rising Asset Management). Copper, lignite coal, potash, gold and tin are key mineral assets for Laos, and together metals and minerals accounted for 40 per cent of the country's export earnings by value in 2012 (United States Geological Survey 2014). As with many other national contexts, in Laos a focus on large-scale mining capital has shifted policy attention away from support for ASM livelihoods. The last decade has also witnessed the entrance of medium-scale regional investors and mining work teams (Vientiane Times 2014a), undertaking unregulated in-land and river mining activities with backhoe excavators, pump dredges, sluices and/or floating dredging platforms. This mediumscale mechanised mining, drawing in workers, operators and investors from China and Vietnam, occurs through some level of local government 
permission, and the operations have often caused a significant amount of environmental degradation (International Union for Conservation of Nature Laos 2005; Vientiane Times 2010a, 2010b, 2010c, 2013; Land Information Working Group 2012).

Lao PDR's updated 2011 Law on Minerals maintains legal protection for informal mining; however, these rights are within poorly defined limits of mechanisation. In practice, a range of ASM and more mechanised informal gold-mining is occurring across the country (with periodic booms in other minerals that can be accessed through small-scale techniques, such as alabaster). In 2012, the Government of Laos (GoL) announced a moratorium on new concessions for mining, as a result of the uncoordinated allocations of mining concessions by all levels of government and the resultant stream of negative socio-environmental impacts, as well as losses in national revenue to the Treasury. The 2012 ban on new mining concessions led to uncertainty around how local officials should regulate ASM, and has facilitated (selective) enforcement against informal mining. Reports from the Vientiane Times (2014a) indicate that the Laos National Assembly:

asked the government to formulate regulations to govern small-scale mining and mineral extraction projects, including those carried out by locals, after learning that the operations were causing significant environmental damage.

The Ministry of Planning and Investment subsequently undertook a nation-wide inspection and survey of mining concession agreements and operations (Schoenweger et al. 2012; Vientiane Times 2015). The ban on new mining concessions has been extended into late 2016 (Vientiane Times 2016); however, the small- to medium-scale mining operations have continued to come under policy pressure since then (Vientiane Times 2014b; Radio Free Asia 2016). There have been reports of arrests of local Lao miners tunnelling for hard-rock gold deposits in central Xieng Khouang Province in recent years, in part related to safety concerns (Vientiane Times 2014c), and there were reports of a number of deaths due to tunnel collapses.

The research of Chansouk Insouvanh (2015) in Xaysoumboun Province, central Laos, highlights how one community decided to sell communal land to an ersatz 'ecotourism' venture, rather than experience what was likely to be uncompensated losses of communal land due to a state-backed rubber plantation project. Such scenarios are not uncommon in Laos 
and are part of the creation of new agrarian class relations in the context of new global investment into natural resource extraction and 'resource frontier' state-society relations (Barney 2009). As the 'ecotourism' venture developed, it morphed into a gold-mining operation, and began to displace local peasant traditions of river gold-panning. While villagers were historically engaged in low-technology gold-panning, they also started to access the gold-bearing soil excavated by the company workers, and an orientation towards this informal gold-mining activity turned into a new means to earn cash income. As with the other cases described above, this example highlights the different social, economic and capital structures of 'informal' gold-mining, and the different capital interests (Verbrugge 2014a) in play, which are often linked in different ways back to state actors.

Fieldwork conducted in 2016 in southern Laos' Xekong and Attapeu provinces highlighted the involvement of joint Lao-Vietnamese mining operations in the remote Annamite uplands along the Vietnamese border. In the upper Xekaman River watershed near the town of Dak Cheung, Lao-Vietnamese mining operations were leasing and digging up stream-side paddy fields, using backhoe excavators and thakeng sluices. One firm engaged in this activity was known locally as Ong Pheuang, reported as a subsidiary of the Vietnamese conglomerate Hoàng Anh Gia Lai (HAGL), a major corporate investor in southern Laos with interests in plantations, hydropower, infrastructure and mining, and with stated mining interests in Xekong Province. A retired district official indicated that Ong Pheuang had purchased their mining licence from a previous Chinese investor named Jiang Kham company, and then sold it onwards to another Vietnamese firm called Hui That. Another Chinese investor had been engaged in similar gold-mining operations in the district, which were halted after the firm did not pay taxes to the district authorities (fieldwork interviews, Dak Cheung, 12 March 2016).

The lack of transparency and public information on these medium-scale mining arrangements in remote areas of rural Laos, and their generally quasi-legal status, makes this a difficult and nebulous area to research and understand. Fieldwork highlighted that villagers are largely left to their own devices on negotiations when outsiders arrive and request access to community land for mining. Local land brokers might also serve as intermediaries between village leaders and gold-mining firms in these transactions. Villagers can be faced with unresponsive district governors when the mining firms renege on their (verbal) agreements 
with community leaders. District authorities are in turn constrained in controlling mining operations when they are subsidiaries of large and politically connected external corporate investors in Laos, such as HAGL. There was no indication of any formal regulation of these operations by the Ministry of Natural Resources and Environment. While recently the Lao Government announced a crackdown in provincial Attapeu on unregulated mining (Radio Free Asia 2016), there has been little mention of enforcement against transborder medium-scale mining in other provinces, such as in nearby Xekong.

Marginalised ethnic Katu villagers in the upper Xekaman watershed have little previous experience with such mining operations; indeed, we encountered a series of villages where backhoe mining had caused extensive and likely irreparable damage to wet rice paddy land, which also spilled over to affect nearby landowners who did not lease their land. Compensation by the companies to landowners for a mining 'lease' was reported at a meagre LAK10,000-15,000 (US\$1.21-1.82) per square metre for productive stream-side wet rice paddy land. These local agreements purportedly require the mining firms to retill and prepare the soil for a resumption of wet rice paddy cultivation at the end of their operations. In reality, the soil structure can be so thoroughly degraded after intensive sluice mining that the resumption of agriculture is rendered impossible. Villagers reported that staff from mining operations, such as Ong Pheuang, also engage in opportunistic illegal logging during their periods of work in the village locations. Such intensive mining operations also remove any future potential for villagers' own small-scale panning for gold in their local streams and rivers, a livelihood option previously shared by men and women (Baird and Shoemaker 2008).

In the deep south of Laos' Attapeu Province, artisanal (non-mechanised) miners are active in upland locations, such as in the Dong Amphan National Protected Area. One local miner reported yields for dry season stream-side panning for gold at 2-3 'houn' of gold per day (worth US $\$ 33.20-49.80$ ), or 1 'baht' per 20 days (US\$666). ${ }^{13}$ For this yield, his cash income over two days in March 2016 reached LKP170,000 (US\$20.59), which was a much better option compared to working as

13 According to this Lao measurement system, there are 10 'houn' in 1 'saleung', and 4 'saleung' in 1 'baht' of gold. Field interviews in 2016 indicated that 1 Lao 'baht' of gold represented a value of approximately LKP5.5 million (US\$666), representing about 15 grams of gold. Using world gold prices as of March 2016, 1 'houn' of gold might then represent approximately US\$16.60. 
a labourer in nearby HAGL rubber plantations (at LKP40,000 per day; US\$4.84). Working as a smallholder gold panner had the added benefit of flexibility, and maintaining his independence and autonomy outside of the disciplinary surveillance of plantation company supervisors (fieldwork interviews, 16 March 2016).

Similar to the other contexts studied in this chapter, Laos demonstrates a highly complex and dynamic landscape, involving both artisanal and more mechanised forms of gold extraction. A nuanced understanding of the actors, provincial and cross-border capital connections, livelihoods and environmental impacts of ASM is required for considering effective policy interventions. In Laos, one might imagine strengthening legal rights for certain forms of informal mining, in combination with better regulation and oversight for other patterns of mining that are producing more negative social and environmental outcomes. For example, a politically empowered 'mobile informal mining monitoring unit', sponsored by the GoL and donor partners could quite quickly develop an accurate and updated assessment of all the different actors and types of informal mining occurring in rural and upland Laos, and their 'capital interests', as a basis for devising more effective policy interventions that are also responsive to local people's circumstances and resource-based livelihoods.

\section{Reassembling informal gold-mining for development and sustainability?}

In India, Indonesia and Laos, reforms to the regulatory framework for small-scale mining have been at best uneven and halting, while the vast majority of policy focus has been on large-scale mining. There is currently little policy learning on informal mining across Asian countries, although much greater sharing of best-practice approaches could be promoted. This study has provided insights into the potential pathways and limits to formalisation beyond a technical policy 'fix'. By viewing informal goldmining as a rational livelihood opportunity that many different people are engaged in, we can move beyond discussions of 'short-term greed' and allegations of the ASM's various 'social ills'. While I do not seek to underplay the significance of social and environmental concerns, for the most part I have found that informal gold miners are everyday people and family members, making a living under less-than-ideal circumstances. Quite simply, gold-mining can offer a better livelihood than is available from various alternatives, even though there are risks, and the financial 
benefits are unequally distributed amongst the participants. Much of this ASGM activity does indeed come at a direct cost for agricultural lands, forests and waterways, and problems such as mercury contamination can become very serious public health issues. Yet, small-scale gold miners are hardly alone in trading off daily income in exchange for compromises on longer-term issues of health and ecological sustainability.

In Jharkhand, India, promoting the basic right of artisanal operators to mine (involving rights over land, rights to extract and trade gold and rights to safe working conditions) could assist with alleviating conditions of extreme poverty. This would entail a reorientation of an (at times) coercive relationship between state actors and the rural poor, and would require supporting the ability of miners to advocate on their own behalf through collective organisations. In comparison, in Central Kalimantan, informal mining occurs on a greater scale, and is far more mechanised and capitalised. Here, there is arguably a stronger potential for formalisation, although the relationships between informal mining operations, financiers, state patronage and power, struggles over territory and natural resources and new agrarian class formation needs to be placed within the frame of analysis. In Laos, formalising ASM policies and regulations are hampered by a non-transparent regime of extraction, where capitalised informal mining continues with the apparent backing from state actors. Domestic and cross-border medium-scale investors and backhoe miners are certainly producing negative impacts for marginalised upland ethnic minority communities, even though artisanal gold-mining can offer, for some, an alternative from commodified labour relations in Laos' corporate resource economy.

The diversity of sites, actors, practices, capital connections and agrarianecological outcomes encompassed by 'artisanal and small-scale' (and 'medium-scale') gold-mining in India, Indonesia and Laos makes this a highly complex and indeed challenging area of resource studies. Considering ASGM as variegated 'assemblages' of informal mining can help to understand how different components of ASM and scales of mechanisation and extraction are organised, institutionalised and territorialised in different places. We need better information on the key logics through which informal mining is situated in relation to local institutions, labour structures, agrarian relations, systems of enclosure and displacements over land and political power and patronage, as well as how informal mining production connects into global value chains. 
Participatory initiatives could start by identifying policy options that are responsive to collective political actions and social mobilisations, from both miners and broader local communities.

Understanding the material, social and political-economic basis for ASGM, miners' livelihood motivations and the variegated 'conditions of informality' that characterise local people's mining is therefore a crucial precondition for effective policy intervention. However, I also suggest that we should not be overly optimistic for fully formalising and regularising the vast and undocumented (perhaps undocumentable) ASGM in Asia, thereby 'solving' associated social-environmental challenges. Some of the ASGM occurring across the region is simply too dispersed, small in scale and of marginal economic value to attract significant project or state-based support. For this 'micro'-artisanal gold-mining, limited formalisation in the form of lifting the burden of illegality, and rolling back systems of petty official rent-seeking, could be the most immediate 'pro-poor' options available. Moving towards the medium-scale of the informal mining spectrum, involving use of machinery and more valuable gold deposits, zoning and use rights acceptable to local communities could be devolved for local benefit with the support of state governments, while also avoiding costly and highly bureaucratic formalisation procedures. State or donor support packages could also target more capitalised and mechanised (and, often, more environmentally problematic) mining activities that fall outside of the artisanal or small-scale range, with a focus on dialogue, establishing and enforcing community zoning regulations, working towards professionalisation, promoting workplace safety and improved environmental standards, and providing access to credit and technology, with the aim of shifting this activity into the fully formal sector (Maconachie and Hilson 2011).

Divorced from local politics and a responsiveness to both miners' and local communities' collective actions, formalisation will remain on the margins of policy development. Given elevated gold prices, in this scenario, informal gold-mining is likely to simply continue to churn through South and Southeast Asia's forest lands, rice fields and rivers. As an alternative, international and donor projects can engage in ASM in a politically informed manner, starting with supporting local collective actions, local institutions and social movements, to build a grounded, responsive and practical framework. Similar challenges have long been apparent in many other resource sectors in Asia (for instance, forests and fisheries), even if the environmental and social challenges posed by informal mining 
can at times be especially stark. Building a formalisation framework that takes a broader view of regulation that includes community norms and standards, and that links community-based resource management with local governance initiatives, has provided innovative alternatives to failed top-down coercive legal enforcement in natural resource management in Asia (e.g. Tyler 2006). In certain contexts of highly intensive, mediumscale mechanised gold-mining, such as that occurring in Central Kalimantan, this would mean accepting that there will likely be less-thanideal trade-offs between local ecologies, resource access and mineral-based income streams and livelihoods, and that progress will be challenging and incremental. Downwardly accountable and locally responsive state institutions and an appreciation of the historical logics that support ASM within the vast 'informal economy' of many developing Global South countries are conditions for these interventions. The challenges of building such effective state institutions, for reassembling more locally beneficial and sustainable mining practices, are where much of the conundrum of ASM lies.

\section{References}

Agrawal, S., 2007. Community Awareness on Hazards of Exposure to Mercury and Supply of Equipment for Mercury-cleaner Gold Processing Technologies in Galangan, Central Kalimantan, Indonesia. Palankaraya: Yayasan Tambuhak Sinta.

Akram-Lodhi, A.H., and C. Kay, 2010. 'Surveying the Agrarian Question (Part 2): Current Debates and Beyond.' Journal of Peasant Studies 37(2): 255-84. doi.org/10.1080/03066151003594906

Baird, I. and B. Shoemaker, 2008. People, Livelihoods, and Development in the Xekong River Basin, Laos. Bangkok: White Lotus Press.

Barney, K., 2009. 'Laos and the Making of a "Relational" Resource Frontier.' Geographical Journal 175(2): 146-59. doi.org/10.1111/ j.1475-4959.2009.00323.x

Barreto, L., 2011. Analysis for Stakeholders on Formalization in the Artisanal and Small-Scale Gold Mining Sector based on Experiences in Latin America, Africa and Asia. Alliance for Responsible Mining. Available 
at commdev.org/wp-content/uploads/2015/06/Analysis-stakeholdersformalization-artisanal-and-small-scale-gold-mining-sector-basedexperiences-Latin-America-Africa-Asia.pdf

Bose, T., 2015. Gold Hunt in the Subarnarekha. Viewed at asmasiapacific. org/wp-content/uploads/2015/09/Eastern-India-Case-Study.pdf (site discontinued)

Boungnaphalom, E., 2003. 'Information about the Project Sites in Lao PDR.' Report to the Global Mercury Project. Vienna: United Nations Industrial Development Organization.

Bridge, G., 2002. 'Grounding Globalization: The Prospects and Perils of Linking Economic Processes of Globalization to Environmental Outcomes.' Economic Geography 78(3): 361-86. doi. org/10.2307/4140814

Buxton, A., 2013. Responding to the Challenge of Artisanal and Small Scale Mining: How Can Knowledge Networks Help? London: International Institute for Environment and Development. Available at pubs.iied. org/16532IIED/

Collier, S.J. and A. Ong (eds), 2005. Global Assemblages: Technology, Politics, and Ethics as Anthropological Problems. Malden, MA: Blackwell.

Cuddy, A. and P. Seangly, 2015. 'Going Straight into the "Forest of Gold."' Phnom Penh Post, 1 August.

Deb, M., G. Tiwari, and K. Lahiri-Dutt, 2008. 'Artisanal and Small-Scale Mining in India: Selected Studies and an Overview of the Issues.' International Journal of Mining, Reclamation and Environment 22(3): 194-209. doi.org/10.1080/17480930701679574

De Soto, H., 2000. The Mystery of Capital. New York: Basic Books.

Dwyer, M., 2015. 'The Formalization Fix? Land Titling, Land Concessions and the Politics of Spatial Transparency in Cambodia.' Journal of Peasant Studies 42(5): 903-28. doi.org/10.1080/03066150.2014.99 4510

Ferring, D., H. Hausermann, and E. Effah, 2016. 'Site Specific: Heterogeneity of Small-Scale Gold Mining in Ghana.' The Extractive Industries and Society 3: 171-84. doi.org/10.1016/j.exis.2015.11.014 
Financial Times, 2014. 'Mongolia Tames 'Ninja' Gold Miners to Support Currency.' 5 March. Available at blogs.ft.com/beyondbrics/2014/03/05/mongolia-tames-ninja-gold-miners-to-supportcurrency/\#axzz2v7TeU9Hs

Fold, N., J. Jonsson, and P. Yankson, 2014. 'Buying Into Formalization? State Institutions and Interlocked Markets in African Small Scale Gold Mining.' Futures 62: 128-39. doi.org/10.1016/j.futures.2013.09.002

Hall, D., 2004. 'Smallholders and the Spread of Capitalism in Rural Southeast Asia.' Asia Pacific Viewpoint 45(3): 401-14. doi. org/10.1111/j.1467-8373.2004.00248.x

Hart, K., n.d. 'Informal Economy.' Available at thememorybank.co.uk/ papers/informal-economy/

Harvard Kennedy School, 2011. From Reformasi to Institutional Transformation: A Strategic Assessment of Indonesia's Prospects for Growth, Equity and Democratic Governance. Cambridge, MA: Harvard Kennedy School Indonesia Program.

Hatcher, P., 2015. 'Neoliberal Modes of Participation in Frontier Settings: Mining, Multilateral Meddling, and Politics in Laos.' Globalizations 12(3): 322-46. doi.org/10.1080/14747731.2015.1016305

Hilson, G., 2013. “'Creating” Rural Informality: The Case of Artisanal Gold Mining in Sub-Saharan Africa.' SAIS Review of International Affairs 33(1): 51-64. doi.org/10.1353/sais.2013.0014

Hilson, G., 2014. 'The Minamata Convention: Exactly What Are We Doing?' Field Diary \& Development Anecdotes. 10 November. Available at asmfielddiary.blogspot.co.id/2014/11/the-minamataconvention-exactly-what.html?spref=tw

Hilson, G. and A. Gatsinzi, 2014. 'A Rocky Road Ahead? Critical Reflections on the Future of Small-Scale Mining in Sub-Saharan Africa.' Futures 62: 1-9. doi.org/10.1016/j.futures.2014.05.006

Insouvanh, C., 2015. Khmu Ethnic Group Women in Artisanal Gold Mining. Paper presented at the Between the Plough the Pick: Informal Mining in the Contemporary World Conference, Canberra, The Australian National University, 5-6 November. 
International Crisis Group (ICG), 2001. Communal Violence in Indonesia: Lessons from Kalimantan. Report No. 19. Jakarta/Brussels: ICG Asia.

International Union for Conservation of Nature Laos, 2005. Gold Mining in Attapeu. Vientiane: Mekong Wetlands Biodiversity Conservation and Sustainable Use Programme.

Kibreab, G., 2000. 'Common Property Resources and Resettlement.' In M. Cernea and C. McDowell (eds), Risks and Reconstruction: Experiences of Resettlers and Refugees. Washington, DC: World Bank.

Labonne, B., 2014. 'Who is Afraid of Artisanal and Small-Scale Mining (ASM)?' The Extractive Industries and Society 1: 121-3. doi. org/10.1016/j.exis.2014.03.002

Lahiri-Dutt, K., 2004. 'Informality in Mineral Resource Management in Asia: Raising Questions Relating to Community Economies and Sustainable Development.' Natural Resources Forum 28: 123-32. doi. org/10.1111/j.1477-8947.2004.00079.x

Land Issues Working Group, 2012. 'Mining in Nonghet, Chameun Village.' Lao Land Issues. Available at www.laolandissues.org/wpcontent/uploads/2012/01/Case-Xieng-Khouang-Gold-MiningChameun-village-Nonghet.pdf

Langston, J., M. Lubis, J. Sayer, C. Margules, A. Boedhihartono and P. Dirks, 2015. 'Comparative Development Benefits from Small and Large Scale Mines in North Sulawesi, Indonesia.' The Extractive Industries and Society 2(3): 434-44. doi.org/10.1016/j.exis.2015.02.007

Li, T.M., 2000. 'Articulating Indigenous Identity in Indonesia: Resource Politics and the Tribal Slot.' Comparative Studies in Society and History 42(1): 149-79. doi.org/10.1017/S0010417500002632

Li, T.M., 2007. 'Practices of Assemblage and Community Forest Management.' Economy and Society 36(2): 263-93. doi. org/10.1080/03085140701254308

Lingga, M., 2016. 'Polres Katingan Amankan 5 Penambang Emas Ilegal.' Tribrata News, 28 August. Available at www.tribratanews.com/polreskatingan-amankan-5-penambang-emas-ilegal/ 
MacDonald, K., M. Lund, M. Blanchette and C. Mccullough, 2013. 'Regulation of Artisanal Small Scale Gold Mining (ASGM) in Ghana and Indonesia as Currently Implemented Fails to Adequately Protect Aquatic Ecosystems.' Proceedings of International Mine Water Association Symposium. Xuzhou, China: IMWA.

Maconachie, R. and G. Hilson, 2011. 'Safeguarding Livelihoods or Exacerbating Poverty? Artisanal Mining and Formalization in West Africa.' Natural Resources Forum 35: 293-303. doi.org/10.1111/ j.1477-8947.2011.01407.x

McCarthy, J., 2013. 'Tenure and Transformation in Central Kalimantan: After the "Million Hectare" Project.' In Anton Lucas and Carol Warren (eds), Land for the People: The State and Agrarian Conflict in Indonesia. Athens: Ohio University Press.

Mitchell, T. 2002. Rule of Experts: Egypt, Techno-Politics, Modernity. Berkeley: University of California Press.

O'Faircheallaigh, C., A. Regan, D. Kikira and S. Kenema, 2016. SmallScale Mining in Bougainville: Impacts and Policy Responses: Interim report on Research Findings. Griffith University. Available at ssgm.bellschool. anu.edu.au/sites/default/files/news/related-documents/2016-07/ interimresearchfindings_ssm_bougainville_260516.pdf

Otsuka, K., J. Estudillo, and T. Yamano, 2010. 'The Role of Labour Markets and Human Capital in Poverty Reduction: Evidence from Asia and Africa.' Asian Journal of Agriculture and Development 7(1): 23-40.

Ouma, S., M. Boeckler and P. Lindner, 2013. 'Extending the Margins of Marketization: Frontier Regions and the Making of AgroExport Markets in Northern Ghana.' Geoforum 48: 225-35. doi. org/10.1016/j.geoforum.2012.01.011

Peluso, N.L., 2016. 'The Plantation and the Mine: Agrarian Transformation and the Remaking of Land and Smallholders in Indonesia.' In J. McCarthy and K. Robinson (eds), Land and Development in Indonesia: Searching for the People's Sovereignty. Singapore: ISEAS, Yusof Ishak Institute. 
Peluso, N.L., 2018. 'Entangled Territories in Small-Scale Gold Frontiers: Labor Practices, Property, and Secrets in Indonesian Gold Country.' World Development 101: 400-16. doi.org/10.1016/j. worlddev.2016.11.003

Peluso, N.L., A. Kelly and K. Woods, 2012. Context in Land Matters: The Effects of History on Land Formalisations. Bogor: Centre for International Forestry Research.

Probe Alert, 1991. Subarnarekha Project in India: Uproots Tribal People, Transforms River Basin. September. Toronto: Probe International. Available at probeinternational.org/library/wp-content/uploads/2011/ 04/September-1991-Probe-Alert.pdf

Purevjav, B., 2011. 'Artisanal and Small-Scale Mining: Gender and Sustainable Livelihoods in Mongolia.' In K. Lahiri-Dutt (ed.), Gendering the Field: Towards Sustainable Livelihoods for Mining Communities. Canberra: ANU E Press.

Putzel, L., A. Kelly, P. Cerutti and Y. Artati, 2014. Formalization of Natural Resource Access and Trade: Insights from Land Tenure, Mining, Fisheries, and Non-Timber Forest Products. Bogor: Centre for International Forestry Research.

Radio Free Asia, 2016. 'Laos Bans New Mining Projects in a Polluted Province.' 27 June. Available at www.rfa.org/english/news/laos/ projects-06272016135647.html

Reno, W., 1999. Warlord Politics and African States. Boulder, CO: Lynne Rienner.

Schoenweger, O., A. Heinemann, M. Epprecht, J. Lu and P. Thalongsengchanh, 2012. Concessions and Leases in the Lao PDR: Taking Stock of Land Investments. Centre for Development and Environment, University of Bern. Bern and Vientiane: Geographica Bernensia.

Shah, A., 2013. 'The Agrarian Question in a Maoist Guerrilla Zone: Land, Labour and Capital in the Forests and Hills of Jharkhand India.' Journal of Agrarian Change 13(3): 424-50. doi.org/10.1111/ joac. 12027 
Siegel, S. and M. Veiga, 2009. 'Artisanal and Small-Scale Mining as an Extra-Legal Economy: De Soto and the Redefinition of "Formalization".' Resources Policy 34: 51-6. doi.org/10.1016/j. resourpol.2008.02.001

Singo, P. and E. Levin, 2016. 'What Mongolia's Artisanal Miners Are Teaching Us: The Link between Human Rights and Artisanal and Small-Scale Mining (ASM) Formalisation.' OECD Insights, 16 March. Available at oecdinsights.org/2016/03/16/mongolias-artisanal-miners/

Spiegel, S., 2009. 'Resource Policies and Small-Scale Gold Mining in Zimbabwe.' Resources Policy 34: 39-44. doi.org/10.1016/j. resourpol.2008.05.004

Spiegel, S., 2012. 'Governance Institutions, Resource Rights Regimes, and the Informal Mining Sector: Regulatory Complexities in Indonesia.' World Development 40(1): 189-205. doi.org/10.1016/j. worlddev.2011.05.015

Spiegel, S., 2016. "Land and "Space" for Regulating Artisanal Mining in Cambodia: Visualizing an Environmental Governance Conundrum in Contested Territory.' Land Use Policy 54: 559-73. doi.org/10.1016/j. landusepol.2016.03.015

Tschakert, P., 2009a. 'Digging Deep for Justice: A Radical Re-imagination of the Artisanal Gold Mining Sector in Ghana.' Antipode 41(4): 70640. doi.org/10.1111/j.1467-8330.2009.00695.x

Tschakert, P., 2009b. 'Recognizing and Nurturing Artisanal Mining as a Viable Livelihood.' Resources Policy 34: 24-31. doi.org/10.1016/j. resourpol.2008.05.007

Tschakert, P., 2016. 'Shifting Discourses of Vilification and the Taming of Unruly Mining Landscapes in Ghana.' World Development 86: 12332. doi.org/10.1016/j.worlddev.2016.05.008

Tyler, S. (ed.), 2006. Communities, Livelihoods and Natural Resources: Action Research and Policy Change in Asia. Ottawa: International Development Research Centre. doi.org/10.3362/9781780440101 
United Nations Environment Programme (UNEP), 2012. Analysis of Formalization Approaches in the Artisanal and Small-Scale Gold Mining Sector: Mongolia Case Study. UNEP, June. Available at wedocs. unep.org/bitstream/handle/20.500.11822/11630/Case_Studies_ Mongolia_June_2012.pdf?sequence $=1 \&$ isAllowed $=\mathrm{y}$

United Nations Institute for Training and Research (UNITAR), 2016. Satellite Mapping of Artisanal and Small Scale Gold Mining in Central Kalimantan, Indonesia. UNITAR, United Nations Environment Programme (UNEP). Available at www.unitar.org/unosat/map/2368

United States Geological Survey, 2014. 2012 Minerals Yearbook: Laos. November. US Department of the Interior, US Geological Survey.

Vandergeest, P., S. Ponte, and S. Bush, 2015. 'Assembling Sustainable Territories: Space, Subjects, Objects, and Expertise in Seafood Certification.' Environment and Planning A 47: 1-19. doi.org/ $10.1177 / 0308518 X 15599297$

Veiga, M. (n.d.). Artisanal Mining: Perspectives from the Field. Viewed at globaldialogue.info/Nov1_ASM_2013/IGF\%202013\%20-\%20 Artisanal\%20Mining_\%20Perspectives\%20From\%20the\%20 Fiels\%20-\%20Marcello\%20Veiga.pdf (site discontinued)

Verbrugge, B., 2014a. 'Capital Interests: A Historical Analysis of the Transformation of Small-Scale Gold Mining in Compostela Valley province, Southern Philippines.' The Extractive Industries and Society 1: 86-95. doi.org/10.1016/j.exis.2014.01.004

Verbrugge, B., 2014b. 'Artisanal and Small-Scale Mining: Protecting Those "Doing the Dirty Work".' IIED Briefing Note, October 2014. Available at pubs.iied.org/17262IIED

Verbrugge, B., 2015a. 'Undermining the State? Informal Mining and Trajectories of State Formation in Eastern Mindanao, Philippines.' Critical Asian Studies 47(2): 177-99. doi.org/10.1080/14672715.20 15.997973

Verbrugge, B., 2015b. 'The Economic Logic of Persistent Informality: Artisanal and Small-Scale Mining in the Southern Philippines.' Development and Change 46(5): 1023-46. doi.org/10.1111/ dech.12189 
Verbrugge, B. and B. Besmanos, 2016. 'Formalizing Artisanal and SmallScale Mining: Whither the Workforce?' Resources Policy 47: 134-41. doi.org/10.1016/j.resourpol.2016.01.008

Verbrugge, B., J. Cuvelier, and S. Van Bockstael, 2015. 'Min(d)ing the Land: The Relationship Between Artisanal and Small-Scale Mining and Surface Land Arrangements in the Southern Philippines, Eastern DRC and Liberia.' Journal of Rural Studies 37: 50-60. doi. org/10.1016/j.jrurstud.2014.11.007

Vientiane Times, 2010a. 'Attapeu Villagers Troubled by Muddy Waters.' 17 May.

Vientiane Times, 2010b. 'Gold Diggers Detained in Vientiane Province.' 15 February.

Vientiane Times, 2010c. 'Illegal Gold Mine Poisons Water Sources.' 26 March.

Vientiane Times, 2013. 'Unregulated Mining Poses Environmental Threat.' 16 September.

Vientiane Times, 2014a. 'Chinese Firm Escapes After Illegally Mining for Gold.' 29 July.

Vientiane Times, 2014b. 'Govt Tackles Illegal Gold Mining in Provinces.' 10 April.

Vientiane Times, 2014c. 'Illegal Gold Mining in Xieng Khouang Ends.' 26 September.

Vientiane Times, 2015. 'Many Miners Found to be in Violation of Agreements.' 12 March.

Vientiane Times, 2016. 'PM Announces Continued Suspension of Mining Concessions.' 20 October.

World Bank, 2013. Artisanal and Small-Scale Mining. 21 November. Available at www.worldbank.org/en/topic/extractiveindustries/brief/ artisanal-and-small-scale-mining 
This text is taken from Between the Plough and the Pick: Informal, artisanal and small-scale mining in the contemporary world, edited by Kuntala Lahiri-Dutt, published 2018 by ANU Press, The Australian National University, Canberra, Australia.

doi.org/10.22459/BPP.03.2018.16 